\title{
sciendo
}

DOI: $10.2478 / f v-2020-0011$

FOLIA VETERINARIA, 64, 2: 1-10, 2020

\section{FOODBORNE PATHOGENS ON MEAT STORED IN MAJOR CENTRAL COLD ROOMS IN IBADAN AND THEIR SUSCEPTIBILITY TO ANTIMICROBIAL AGENTS}

\author{
Adesokan, H. K., Funso-Adu, K., Okunlade, O. A. \\ Department of Veterinary Public Health and Preventive Medicine, University of Ibadan \\ Nigeria \\ greaterglory2008@gmail.com
}

\section{ABSTRACT}

Foodborne pathogens are the leading cause of illness and death in developing countries and are often associated with poor hygiene and unsafe food storage conditions. Using central cold rooms with alternate power supply in preserving meats due to erratic power supply is common among meat traders in Nigeria. However, the public health safety of the operations of this practice remains un-investigated. We conducted a microbial assessment of aseptically collected meat swabs from three selected major cold rooms in Ibadan for Staphylococcus aureus, Listeria monocytogenes, Salmonella spp. and Escherichia coli using standard procedures. Antibiotic susceptibility was determined using 14 different antibiotics at standard concentrations following KirbyBauer Assays. The data were analysed with Stata 12.0 using bivariate and logistic regression analyses. Of 180 meat swabs collected, $\mathbf{4 2 . 2} \%$ were positive for $S$. aureus, $\mathbf{2 2 . 2}$ \% for L. monocytogenes, $\mathbf{2 0 . 0} \%$ for Salmonella spp. and $6.7 \%$ for E. coli. All of the isolates exhibited total resistance to seven of the antibiotics. Escherichia coli showed the highest resistance to 12 antibiotics, followed by Salmonella spp. (11 antibiotics), L. monocytogenes (10 antibiotics) and S. aureus (7 antibiotics). Sampling locations were significantly associated with the prevalence of L. monocytogenes $(\mathrm{P}=\mathbf{0 . 0 0 8})$ and S. aureus $(\mathrm{P}=\mathbf{0 . 0 0 0})$, but not with Salmonella spp. $(\mathrm{P}=\mathbf{0 . 4 3 5})$ or E. coli $(\mathrm{P}=0.117)$. The study revealed a heavy microbial contamination with major foodborne pathogens characterized by a high level of antibiotic resistance. These findings portend that the current operations associated with the practice of using central cold rooms in meat preservation in Nigeria undermine public health safety and need to be urgently addressed.

Key words: antimicrobial resistance; cold storage; food safety; meat; microbial contamination; public health

\section{INTRODUCTION}

Like most developing countries of the world, Nigeria is facing a food crisis. The diet of most of her populace is 
often protein deficient, with the average animal protein consumption per person per day being $7.9 \mathrm{~g}$ which is far below the $35 \mathrm{~g}$ recommended by the Food and Agriculture Organisation $[21,32]$. This low level of animal protein intake has generated concern as it affects the physical, physiological and mental development of Nigerian youths and the labour force in the country [5]. There is, therefore, the need for conscious efforts towards adequate availability of animal products that are rich in protein, energy, vitamins and minerals required for adequate nutrition. One major animal product that has received attention over the years is meat. Though highly nutritious because of its high biological value protein [8], meat provides a veritable medium for the growth and multiplication of micro-organisms, making it highly perishable, poisonous and unfit for human consumption when contaminated with microbes [34]. This becomes more evident considering the inadequate refrigeration facilities for optimal preservation of meat coupled with erratic power supply that characterizes most developing countries, particularly Nigeria.

Foodborne pathogens pose a significant threat to public health, causing a substantial economic burden both in developed and developing countries [27, 42]. Recent epidemiological studies of world populations show that 420,000 people lose their lives every year due to foodborne diseases, with around one-third of those being five years of age or younger [24]. The recent outbreak of listeriosis in South Africa was the largest ever recorded involving 674 patients as of March 2018, with $27 \%$ mortalities [45]. The identified Listeria strain (L. monocytogenes ST6) was traced back to the processing environment of a manufacturer of a ready-to-eat processed meat product (polony). As a result, 12 of the 15 African countries to which South Africa exports, recalled and banned imports of the affected meat products, while the rest banned imports of all food products [45]. In Nigeria, there have been several reports of cases of illnesses and deaths due to foodborne pathogens $[6,37,39]$, some of which were linked to contaminated meat. Most of the pathogens responsible for diarrhoea in Nigeria are zoonotic, with cattle as an important reservoir for many. Beef consumption has been associated with a nine-fold increase in the odds of experiencing diarrhoeal illness with additional four-fold increase in the odds when consuming beef of poor microbiological quality. The cost associated with meat-borne diarrhoea alone in Nigeria has been estimated at US\$ 156 million [30]. However, proper handling and storage of meat limits the bacterial contamination or multiplication, thus reducing the associated cost due to meat-borne diseases.

The use of central cold rooms, a temperature-controlled facility designed to preserve meats for the teeming population is a common practice among meat traders in developing countries such as Nigeria. This practice is necessitated by irregular power supply which characterizes such countries given the alternative power supply to the facility. However, the public health safety of the operations of this practice in terms of optimal preservation of meats from microbial pathogens is yet to be seen. The aim of this study was to carry out microbial assessment of meats stored in major cold rooms in Ibadan, south-western Nigeria for Escherichia coli, Listeria monocytogenes, Salmonella spp., and Staphylococcus aureus, the four commonly reported pathogens of public health importance as well as to determine their susceptibility to antimicrobial agents.

\section{MATERIALS AND METHODS}

\section{Study site}

This cross-sectional study was carried out in Ibadan, south-western Nigeria between August and November, 2017. Ibadan is the largest city in terms of the geographical area in the country and one of the country's most populous cities with over three million people. The city accommodates a major central abattoir which supplies meat to the teeming population in the city as well as neighbouring communities in the south-western region. Meats are both sold at formal and informal markets mostly on a retail basis. Considering the challenge of storing meats until the next day, the meat traders in the region adopted the practice of storing their meats in central cold rooms powered by alternative power supplies. The study sites were the cold rooms present at Idi Ose and Ojoo areas of Akinyele Local Government Area (LGA), and Oniyanrin area of Ibadan North LGA. These cold rooms were of similar characteristics in terms of capacity, temperature, relative humidity and air circulation. They were small-sized cold rooms of about $1,000 \mathrm{~m}^{3}$ capacity with temperature ranges between 0 and $-20^{\circ} \mathrm{C}$ and relative humidity of between $85-90 \%$ with adequate airflow and uniformity. 


\section{Study population and sampling technique}

The study population comprised all of the central cold rooms in the Ibadan metropolis. The cold rooms at Akinyele and Ibadan North LGAs were selected considering the presence of the state's abattoir and formal major meat markets in these areas. In addition, these cold rooms represented the major meat storage facilities for public meat traders in the Ibadan metropolis. The traders often stored and preserved their meat at the facilities to prevent meat spoilage and the associated decline in quality. The purpose of this study was explained to the managers of the cold rooms in order to seek their consent to swab samples of the meat stored in the cold rooms. Stored beef meats were aseptically swabbed on both dorsal and ventral parts by rolling sterile swabs against about $5 \mathrm{~cm}^{2}$ area of the sampled items during unscheduled visits to the meat storage facilities in order to ensure the real situational assessment regarding the facilities. The samples were taken from the meat which had been stored at the cold room facilities not less than 18 hours. At least two samples were collected per sub-unit of the cold room facilities during each unscheduled visit. The samples were thereafter placed in the transport medium in the respective swab stick containers kept within cold chain and transported to the Food and Meat Hygiene Laboratory, Department of Veterinary Public Health and Preventive Medicine, University of Ibadan, where sample processing took place. Peptone water and Listeria enrichment broth already prepared for the isolation of the respective organisms served as both transport media and selective broth for the incubation of associated organisms. The samples were processed within three hours of collection.

\section{Sample processing}

The swab samples in the broth media were incubated at $37^{\circ} \mathrm{C}$ for 18 to 24 hours and then plated on the four primary agar media (Oxoid Limited, United Kingdom): Mannitol salt agar for Staphylococcus aureus, Listeria selective agar for Listeria monocytogenes, Salmonella-Shigella agar for Salmonella and Eosin-Methylene blue agar for Escherichia coli. After inoculation onto the agar, the Petri dishes were turned upside down and incubated at $37^{\circ} \mathrm{C}$ for another 18 to 24 hours, (24 to 48 hours for Listeria plates only because of its relatively slow growth). After the incubation, the growths on the different media were observed. The most distinct colonies showing perfect morphological characteristics of the desired organisms on each medium were harvested and aseptically sub-cultured and incubated to obtain pure colonies.

Staphylococcus aureus were identified following the use of conventional biochemical methods including Gram staining, catalase, coagulase, sugar fermentation (mannitol, glucose, xylose and arabinose), haemolysis on $5 \%$ sheep blood agar and pigmentation as described by $\mathrm{B}$ a r r o w and $\mathrm{F}$ e $\mathrm{lt}$ h a $\mathrm{m}$ [10]. Listeria monocytogenes were identified as previously described [10] by employing the use of conventional biochemical methods including Gram staining, catalase, aesculin, triple sugar iron (TSI) reaction, motility, urease, sugar fermentation tests (lactose, sucrose, mannitol and xylose), motility and CAMP tests. Similarly, Salmonella isolates were identified by triple-sugar-iron (TSI) agar test and the urease test with a susceptible strain used as a positive control. E. coli was identified following the conventional biochemical tests, including urease production, catalase test, motility, Voges-Proskauer, indole production, carbohydrate fermentation tests, methyl red and citrate utilization.

\section{Antibiotic Sensitivity Test (Kirby-Bauer Assay)}

Antibiotic susceptibility testing was carried out using the Kirby-Bauer disc-diffusion test which was in line with the recommended standard as earlier described [16]. Briefly, an inoculum of each pure bacterial isolate was emulsified using $3 \mathrm{~mL}$ of sterile normal saline and the density thereafter was adjusted to the $0.5 \mathrm{McF}$ arland standard. Inoculations into the Mueller-Hilton Agar (MHA) plates (Oxoid, England) were then carried out by a sterile cotton swab dipped into the standardized suspension of bacterial cultures. The plates were then allowed to dry. Antibiotic discs containing ciprofloxacin $(5 \mu \mathrm{g})$, ofloxacin $(5 \mu \mathrm{g})$, augmentin $(30 \mu \mathrm{g})$, nitrofurantoin $(300 \mu \mathrm{g})$, ampicillin $(10 \mu \mathrm{g})$, ceftazidime $(30 \mu \mathrm{g})$, cefuroxime $(30 \mu \mathrm{g})$, gentamicin $(10 \mu \mathrm{g})$, cotrimoxazole $(25 \mu \mathrm{g})$, chloramphenicol $(10 \mu \mathrm{g})$, cloxacillin $(5 \mu \mathrm{g})$, erythromycin $(5 \mu \mathrm{g})$, streptomycin $(10 \mu \mathrm{g})$, tetracycline $(10 \mu \mathrm{g})$ (Antibiotic Becton Dickinson and Company, Sparks, USA) were placed onto MHA plates. The plates were then incubated at $37^{\circ} \mathrm{C}$ for 24 hours. Finally, the zone of inhibition was measured in millimetres and zone diameters interpreted in accordance with standards as susceptible, intermediate and resistant on the basis of the critical points recommended [16]. S. aureus ATCC 25923, L. monocytogenes ATCC7644, En- 
terococcus faecalis ATCC 29212 and Escherichia coli ATCC 25922 were used as reference strains.

\section{Data Analysis}

The data were analysed using STATA 12 . The frequencies and percentages were calculated as appropriate for the prevalence of each foodborne pathogen. Univariate binary logistic analysis and multivariate logistic regression analysis were conducted to determine the relationships between outcome variable (prevalence of the different foodborne pathogens) and sampling locations. Odds ratios (OR) were computed in order to determine the presence and strength of the associations between variables and $95 \%$ Confidence Intervals (CIs) were calculated to investigate the statistical significance. Values of $\mathrm{P}<0.05$ were considered significant.

\section{RESULTS}

\section{Prevalence of S. aureus, L. monocytogenes,}

\section{Salmonella spp. and $E$. coli in stored meat}

A total of 180 meat swab samples were collected from the three cold rooms, with 60 each from the three locations. Of the foodborne pathogens obtained, $42.2 \%$ were identified as S. aureus, $22.2 \%$ as L. monocytogenes, $20.0 \%$ as Salmonella spp. and $6.7 \%$ as E. coli (Table 1). Of the samples from the cold room at Idi Ose in Akinyele LGA, 52 (86.7 \%) were positive for S. aureus, 4 (6.7 \%) for L. monocytogenes, 16 (26.7\%) for Salmonella spp. and 8 (13.3\%) for E. coli. From Ojoo in Akinyele LGA, 4 (6.7\%) were positive for S. aureus, 24 (40.0\%) for L. monocytogenes, 12 (20.0\%) for Salmonella spp. and none (0.0\%) for E. coli. Again, out of the samples obtained from the cold room at Oniyanrin, Ibadan North LGA, 20 (33.3 \%) were identified as S. aureus, $12(20.0 \%)$ as L. monocytogenes, 8 (13.3\%) as Salmonella spp. and 4 (6.7\%) as E. coli. (Table 1).
Overall, the prevalence of L. monocytogenes was significantly associated with sampling location $(P=0.008)$, with meat from Ojoo and Oniyanrin being about $9(\mathrm{OR}=9.33$, $95 \% \mathrm{CI}: 1.87-46.68, \mathrm{P}=0.007)$ and $3.5(\mathrm{OR}=3.5,95 \%$ CI: $0.65-18.98, \mathrm{P}=0.146$ ) times, respectively; more likely to be contaminated than those from Idi-Ose. Similarly, the prevalence of $S$. aureus was significantly associated with sampling location $(\mathrm{P}=0.000)$, with meat from Ojoo and Oniyanrin being about $100(\mathrm{OR}=0.01,95 \% \mathrm{CI}$ : $0.002-$ $0.065, \mathrm{P}=0.000)$ and $12.5(\mathrm{OR}=0.08,95 \% \mathrm{CI}: 0.021-$ $0.282, \mathrm{P}=0.000)$ times, respectively less likely to be contaminated than that from Idi-Ose. However, sampling location was not significantly associated with the prevalence of Salmonella spp. $(\mathrm{P}=0.435)$ and E. coli $(\mathrm{P}=0.117)$.

\section{Antibiotics susceptibility test}

All of the isolates exhibited total resistance to seven of the 14 antibiotics used and these included ampicillin $(10 \mu \mathrm{g})$, ceftazidime $(30 \mu \mathrm{g})$, cefuroxime $(30 \mu \mathrm{g})$, cotrimoxazole $(25 \mu \mathrm{g})$, chloramphenicol $(10 \mu \mathrm{g})$, cloxacillin $(5 \mu \mathrm{g})$ and erythromycin $(5 \mu \mathrm{g})$ (Table 2$)$. In addition, $84.2 \%$, $100.0 \%, 83.3 \%$ and $50.0 \%$ of all the S. aureus, L. monocytogenes, Salmonella spp. and E. coli isolated were respectively susceptible to ciprofloxacin ( $5 \mu \mathrm{g}$ ) while $84.2 \%$, $100.0 \%, 77.8 \%$ and $50.0 \%$ were susceptible to ofloxacin in the same order (Table 2). Based on the proportion of susceptibility, E. coli exhibited the least susceptibility, being susceptible to only two antibiotics, followed by Salmonella spp. to three antibiotics, and then L. monocytogenes to four; the highest being $S$. aureus with total susceptibility to seven antibiotics (Table 2). Based on the locations of the different cold rooms from where the samples were collected, similar susceptibility and resistance patterns were obtained for the isolates (Table 3). 
Table 1. Prevalence of foodborne pathogens from meat swabs samples obtained from cold rooms across Ibadan metropolis

\begin{tabular}{lccc}
\hline Location & $\begin{array}{c}\text { S. aureus } \\
\text { Number (\%) }\end{array}$ & $\begin{array}{c}\text { L. monocytogenes } \\
\text { Number (\%) }\end{array}$ & $\begin{array}{c}\text { Salmonella spp. } \\
\text { Number (\%) }\end{array}$ \\
\hline Idi Ose & $52(86.7)$ & $4(6.7)$ & $16(26.7)$ \\
Number (\%)
\end{tabular}

Table 2. Antibiotic susceptibility profiles of foodborne pathogens isolated from stored meat from major cold rooms in lbadan

\begin{tabular}{|c|c|c|c|c|c|c|c|c|c|c|c|c|}
\hline \multirow[b]{2}{*}{ Susceptibility patterns* [\%] } & \multicolumn{3}{|c|}{$\begin{array}{l}\text { S. aureus } \\
{[n=76]}\end{array}$} & \multicolumn{3}{|c|}{$\begin{array}{l}\text { L. monocytogenes } \\
{[\mathrm{n}=40]}\end{array}$} & \multicolumn{3}{|c|}{$\begin{array}{l}\text { Salmonella spp. } \\
\qquad[n=36]\end{array}$} & \multicolumn{3}{|c|}{$\begin{array}{l}\text { E. coli } \\
{[n=12]}\end{array}$} \\
\hline & $S$ & I & $\mathrm{R}$ & $S$ & 1 & $\mathrm{R}$ & $S$ & 1 & $\mathrm{R}$ & $S$ & 1 & $\mathrm{R}$ \\
\hline $\begin{array}{l}\text { Ciprofloxacin } \\
{[5 \mu \mathrm{g}]}\end{array}$ & 84.2 & 5.3 & 10.5 & 100.0 & 0.0 & 0.0 & 83.3 & 0.0 & 16.7 & 50.0 & 8.3 & 41.7 \\
\hline $\begin{array}{l}\text { Ofloxacin } \\
{[5 \mu \mathrm{g}]}\end{array}$ & 84.2 & 4.0 & 11.8 & 100.0 & 0.0 & 0.0 & 77.8 & 0.0 & 22.2 & 50.0 & 33.3 & 16.7 \\
\hline $\begin{array}{l}\text { Augmentin } \\
{[30 \mu \mathrm{g}]}\end{array}$ & 65.8 & 2.6 & 31.6 & 0.0 & 15.0 & 85.0 & 0.0 & 33.3 & 66.7 & 0.0 & 33.3 & 66.7 \\
\hline $\begin{array}{l}\text { Nitrofurantoin } \\
{[300 \mu \mathrm{g}]}\end{array}$ & 2.6 & 2.6 & 94.7 & 80.0 & 0.0 & 20.0 & 0.0 & 11.1 & 88.9 & 0.0 & 16.7 & 83.3 \\
\hline $\begin{array}{l}\text { Ampicillin } \\
{[10 \mu \mathrm{g}]}\end{array}$ & 0.0 & 0.0 & 100.0 & 0.0 & 5.0 & 95.0 & 0.0 & 25.0 & 75.0 & 0.0 & 41.7 & 58.3 \\
\hline $\begin{array}{l}\text { Ceftazidime } \\
{[30 \mu \mathrm{g}]}\end{array}$ & 0.0 & 0.0 & 100.0 & 0.0 & 12.5 & 87.5 & 0.0 & 16.7 & 83.3 & 0.0 & 0.0 & 100.0 \\
\hline $\begin{array}{l}\text { Cefuroxime } \\
{[30 \mu \mathrm{g}]}\end{array}$ & 0.0 & 0.0 & 100.0 & 0.0 & 2.5 & 97.5 & 0.0 & 5.6 & 94.4 & 0.0 & 8.3 & 91.7 \\
\hline $\begin{array}{l}\text { Gentamicin } \\
{[10 \mu \mathrm{g}]}\end{array}$ & 73.7 & 7.9 & 26.3 & 65.0 & 7.5 & 27.5 & 0.0 & 22.2 & 77.8 & 0.0 & 8.3 & 91.7 \\
\hline $\begin{array}{l}\text { Cotrinazole } \\
{[25 \mu \mathrm{g}]}\end{array}$ & 0.0 & 10.5 & 89.5 & 0.0 & 25.0 & 75.0 & 0.0 & 2.8 & 97.2 & 0.0 & 25.0 & 75.0 \\
\hline $\begin{array}{l}\text { Chloramphenicol } \\
{[10 \mu \mathrm{g}]}\end{array}$ & 0.0 & 7.9 & 92.1 & 0.0 & 20.0 & 80.0 & 0.0 & 0.0 & 100.0 & 0.0 & 50.0 & 50.0 \\
\hline $\begin{array}{l}\text { Cloxacillin } \\
{[5 \mu \mathrm{g}]}\end{array}$ & 0.0 & 19.7 & 80.3 & 0.0 & 27.5 & 72.5 & 0.0 & 13.9 & 86.1 & 0.0 & 16.7 & 83.3 \\
\hline $\begin{array}{l}\text { Erythromycin } \\
{[5 \mu \mathrm{g}]}\end{array}$ & 0.0 & 6.6 & 93.4 & 0.0 & 15.0 & 85.0 & 0.0 & 5.6 & 94.4 & 0.0 & 8.3 & 91.7 \\
\hline $\begin{array}{l}\text { Streptomycin } \\
{[10 \mu \mathrm{g}]}\end{array}$ & 13.2 & 3.9 & 82.9 & 0.0 & 22.5 & 77.5 & 22.2 & 2.8 & 75.0 & 0.0 & 33.3 & 66.7 \\
\hline $\begin{array}{l}\text { Tetracycline } \\
{[10 \mu \mathrm{g}]}\end{array}$ & 21.0 & 13.2 & 65.8 & 0.0 & 7.5 & 92.5 & 0.0 & 0.0 & 100.0 & 0.0 & 0.0 & 100.0 \\
\hline
\end{tabular}

*_Susceptible; I-Intermediate; R-Resistant 


\begin{tabular}{|c|c|c|c|c|c|c|c|c|c|c|c|}
\hline \multirow{2}{*}{$\begin{array}{l}\text { Cold room location } \\
\\
\text { Foodborne } \\
\text { pathogens }\end{array}$} & \multicolumn{4}{|c|}{ Idi-Ose } & \multicolumn{3}{|c|}{ Ojoo } & \multicolumn{4}{|c|}{ Oniyanrin } \\
\hline & 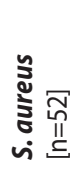 & 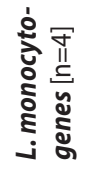 & 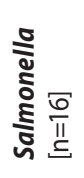 & 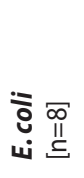 & 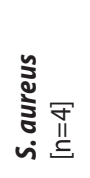 & 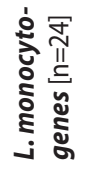 & 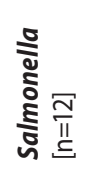 & 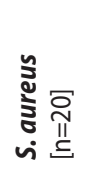 & 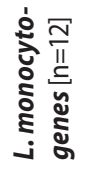 & 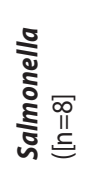 & 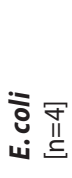 \\
\hline Antibiotic & $\%$ & $\%$ & $\%$ & $\%$ & $\%$ & $\%$ & $\%$ & $\%$ & $\%$ & $\%$ & $\%$ \\
\hline $\begin{array}{l}\text { Ciprofloxacin } \\
{[5 \mu \mathrm{g}]}\end{array}$ & 80.8 & 100.0 & 87.5 & 75.0 & 100.0 & 100.0 & 66.7 & 90.0 & 100.0 & 100.0 & 0.0 \\
\hline $\begin{array}{l}\text { Ofloxacin } \\
{[5 \mu \mathrm{g}]}\end{array}$ & 92.3 & 100.0 & 87.5 & 75.0 & 75.0 & 100.0 & 50.0 & 65.0 & 100.0 & 100.0 & 0.0 \\
\hline $\begin{array}{l}\text { Augmentin } \\
{[30 \mu \mathrm{g}]}\end{array}$ & 73.1 & 0.0 & 0.0 & 0.0 & 50.0 & 0.0 & 0.0 & 50.0 & 0.0 & 0.0 & 0.0 \\
\hline $\begin{array}{l}\text { Nitrofurantoin } \\
{[300 \mu \mathrm{g}]}\end{array}$ & 0.0 & 100.0 & 0.0 & 0.0 & 50.0 & 75.0 & 0.0 & 0.0 & 83.3 & 0.0 & 0.0 \\
\hline $\begin{array}{l}\text { Ampicillin } \\
{[10 \mu \mathrm{g}]}\end{array}$ & 0.0 & 0.0 & 0.0 & 0.0 & 0.0 & 0.0 & 0.0 & 0.0 & 0.0 & 0.0 & 0.0 \\
\hline $\begin{array}{l}\text { Ceftazidime } \\
{[30 \mu \mathrm{g}]}\end{array}$ & 0.0 & 0.0 & 0.0 & 0.0 & 0.0 & 0.0 & 0.0 & 0.0 & 0.0 & 0.0 & 0.0 \\
\hline $\begin{array}{l}\text { Cefuroxime } \\
{[30 \mu \mathrm{g}]}\end{array}$ & 0.0 & 0.0 & 0.0 & 0.0 & 0.0 & 0.0 & 0.0 & 0.0 & 0.0 & 0.0 & 0.0 \\
\hline $\begin{array}{l}\text { Gentamicin } \\
{[10 \mu \mathrm{g}]}\end{array}$ & 76.9 & 100.0 & 0.0 & 0.0 & 100.0 & 58.3 & 0.0 & 60.0 & 66.7 & 0.0 & 0.0 \\
\hline $\begin{array}{l}\text { Cotrinazole } \\
{[25 \mu \mathrm{g}]}\end{array}$ & 0.0 & 0.0 & 0.0 & 0.0 & 0.0 & 0.0 & 0.0 & 0.0 & 0.0 & 0.0 & 0.0 \\
\hline $\begin{array}{l}\text { Chloramphenicol } \\
{[10 \mu \mathrm{g}]}\end{array}$ & 0.0 & 0.0 & 0.0 & 0.0 & 0.0 & 0.0 & 0.0 & 0.0 & 0.0 & 0.0 & 0.0 \\
\hline $\begin{array}{l}\text { Cloxacillin } \\
{[5 \mu \mathrm{g}]}\end{array}$ & 0.0 & 0.0 & 0.0 & 0.0 & 0.0 & 0.0 & 0.0 & 0.0 & 0.0 & 0.0 & 0.0 \\
\hline $\begin{array}{l}\text { Erythromycin } \\
\text { [5 } \mu \mathrm{g}]\end{array}$ & 0.0 & 0.0 & 0.0 & 0.0 & 0.0 & 0.0 & 0.0 & 0.0 & 0.0 & 0.0 & 0.0 \\
\hline $\begin{array}{l}\text { Streptomycin } \\
{[10 \mu \mathrm{g}]}\end{array}$ & 19.2 & 0.0 & 37.5 & 0.0 & 0.0 & 0.0 & 16.7 & 0.0 & 0.0 & 0.0 & 0.0 \\
\hline $\begin{array}{l}\text { Tetracycline } \\
{[10 \mu \mathrm{g}]}\end{array}$ & 30.8 & 0.0 & 0.0 & 0.0 & 0.0 & 0.0 & 0.0 & 0.0 & 0.0 & 0.0 & 0.0 \\
\hline
\end{tabular}




\section{DISCUSSION}

Foodborne diseases occur worldwide, including those acquired through the consumption of contaminated meat [3]. Microbial contaminated meat and meat products especially due to bacterial pathogens remain the most serious meat safety issue resulting in immediate consumer health problems and product recalls from the marketplace [26, 43]. The results of this study revealed heavy microbial contamination in meat from the cold rooms in Ibadan with an associated high level of resistance to major antibiotics. These findings indicate that raw meat remains a potential medium for the multiplication of foodborne pathogens, particularly bacteria and a likely source of antibiotic resistance development in human consumers. This observation is of serious public health concern since meat is a major source of animal proteins and most consumers do not translate their knowledge of food safety when handling meat into practice. Thus, they are exposed especially to the toxins produced by pathogens which are not readily inactivated by heat $[1,4]$. Microbial contamination of meat and meat products renders the meat unwholesome and unfit for human consumption [20]. Meanwhile, most of such contaminations often occur at major critical points in the field, during harvesting, processing or distribution, or in retail markets, or foodservice facilities $[19,22,35,40]$.

The high prevalence of the foodborne pathogens isolated from stored meat in this study was unexpected considering the fact that the samples were taken from cold room facilities which were expected to be at the freezing point. A previous report shows that most food pathogens including S. aureus, Salmonella, E. coli do not survive sufficiently low temperatures [29], although L. monocytogenes may grow at temperatures as low as $-2{ }^{\circ} \mathrm{C}$. The observations in this study are therefore suggestive of poor operation and temperature holdings of cold rooms being used in preserving meat in the study area. The fact that the cold room owners were also meat traders themselves made them a sandwich between being informal meat traders and cold room owners. As a result, the meat preserved in the cold rooms were frequently exposed to thawing and freezing cycles when displayed for buyers who patronized the cold rooms. The resultant cycles of thawing and freezing could enhance microbial multiplication. These micro-organisms on the meat could proliferate as the temperature approaches the optimum range for their growth in the open air. This connotes a matter of serious public health concern to unsuspecting buyers since a visibly frozen meat in this case does not necessarily imply that it is safe and wholesome. Poor preservation of food including meat and meat products remains a challenge in Nigeria and it is responsible for untold post-harvest losses as well as increasing foodborne illnesses [9].

Notwithstanding the prevalence of $42.2 \%, 22.2 \%$, $20.0 \%$ and $6.7 \%$, respectively, observed for S. aureus, L. monocytogenes, Salmonella spp. and E. coli in this study, higher prevalence has been reported from informal meat markets. For instance, a report [38] indicated prevalence of $94.4 \%, 88.8 \%, 84.7 \%$ and $69.4 \%$ for S. aureus, L. monocytogenes, Salmonella spp. and E. coli, respectively, in both informal and formal markets in the same part of Ibadan metropolis where the present study was carried out. A d e y a n u and I s h o la [2] also obtained prevalence of $33.3 \%$ and $43.4 \%$ for Salmonella and Escherichia coli, respectively in poultry meat in Ibadan, while another study [15] revealed $96.3 \%$ prevalence of $S$. aureus in raw beef in Lafia Metropolis, Nigeria. A higher prevalence of $95.8 \%$ than what was observed in this study (22.2\%) was reported for L. monocytogenes in poultry meat by I s h o l a et al. [31] in Oyo State.

The varying prevalence notwithstanding, the high frequency of these pathogens observed in this study is indicative of unhygienic handling operations of meat during and post-processing. The high prevalence of S. aureus is particularly worrisome since the toxin it produces is heatstable. This pathogen is resistant to high sodium chloride concentration and produces enterotoxins that can withstand high temperature, causing vomiting and diarrhoea when ingested [12]. As previously reported, a staphylococcal toxin dose of less than one microgram in contaminated food can produce symptoms of staphylococcal intoxication [23]. In the same vein, listeriosis has been associated with the consumption of undercooked raw foods contaminated with L. monocytogenes [13]. This disease often results in admission to intensive-care units, making L. monocytogenes the third most costly foodborne pathogen in the USA per case in 2010, after Clostridium botulinum and Vibrio vulnificus [41]. In 2012, an estimated annual cost of L. monocytogenes in the USA was put at US\$ $2-6$ billion [28]. The prevalence of Salmonella spp. in this study is also worthnoting, especially because of its implication in foodborne salmonellosis in humans, due to ingestion of Salmonella 
cells. Previous findings have linked human salmonellosis outbreaks to consumption of contaminated meat $[18,36]$. Also, Escherichia coli has been associated with traveller's diarrhoea and haemorrhagic colitis. Its presence in food is therefore considered a threat to human health, and an indication of gross contamination by human and/or animal faecal matter $[7,44]$.

Further, the level of resistance to antibiotics exhibited by most of the foodborne pathogens isolated in this study calls for serious attention. Antibiotics are commonly used around the world to cure diseases caused by bacteria, but as the World Health Organisation and other international bodies have pointed out; the global increase in antibiotics resistance is a rapidly worsening problem [14]. Since antibiotics are also an essential part of modern medicine as prophylactic treatment, the rising resistance of bacteria presents even more of a danger. As observed in this study, all the isolates exhibited total resistance to ampicillin $(10 \mu \mathrm{g})$, ceftazidime $(30 \mu \mathrm{g})$, cefuroxime $(30 \mu \mathrm{g})$, cotrimoxazole $(25 \mu \mathrm{g})$, chloramphenicol $(10 \mu \mathrm{g})$, cloxacillin $(5 \mu \mathrm{g})$ and erythromycin $(5 \mu \mathrm{g})$. In a study on the emergence of a new antibiotic resistance mechanism in India, Pakistan and the UK [33], 36 isolates of $E$. coli obtained were highly resistant to all antibiotics except tetracycline and colistin. This is in line with the observation in this study as the E. coli isolates were resistant to all, but ciprofloxacin and ofloxacin among the antibiotics used. In a study on the characterization of antimicrobial resistance of foodborne Listeria monocytogenes [17], resistance to linezolid, ciprofloxacin, ampicillin and rifampicin, trimethoprim/sulphamethoxazole, vancomycin and tetracycline were observed among some of the isolates. G o m b a et al. [25] in their study also revealed that the Salmonella isolates assessed were resistant to most of the antibiotics.

On the other hand, the majority of the S. aureus strains in our study were susceptible to ciprofloxacin, ofloxacin and gentamicin. This was similar to the observation of B e r $\mathrm{n}$ a r d et al. [11] in their study to determine the antibiotic sensitivity of $S$. aureus strain responsible for community-acquired skin infections where only $0.5 \%$ of the isolated strains showed resistance to gentamicin. This plausibly indicated that the resistance of $S$. aureus to gentamicin was still generally low.

The above findings notwithstanding, this study has some limitations. One, only three cold room facilities were used as using more facilities would have probably given more insights into the subject. Two, operations and activities of the cold room facilities studied were not investigated; this would have helped determine the factors responsible for the high level of microbial contamination observed.

\section{CONCLUSIONS}

Despite the above limitations, this study revealed that the meats preserved in commercial cold rooms in Ibadan metropolis were heavily contaminated with foodborne pathogens, including S. aureus, L. monocytogenes, Salmonella spp. and E. coli with serious public health implications to the consumers. The high level of antibiotic resistance exhibited by most of the foodborne pathogens isolated is a matter of grave concern to the health of animals as well as meat consumers. The high microbial contamination might be due to exposure to environmental pathogens from multiple handling and during frequent cycles of thawing and freezing of stored meat as well as possible inadequate freezing. Again, indiscriminate use of antibiotics in livestock animals in general by farmers might explain the observed high antibiotic resistance observed among the foodborne pathogens. Improved pre- and post-processing meat handling is advocated. Approaches to lower or control indiscriminate use of antibiotics in animals are also urgently required. There is a need to investigate structural facilities and the management of cold rooms in Nigeria and other developing countries towards ensuring wholesome and safe meat for ultimate human health. Again, there is a need for improved food preservation methods to mitigate the potential health hazards that are associated with the current practice in the study area.

\section{REFERENCES}

1. Adesokan, H. K., Akinseye, V. O., Adesokan, G. A., 2015: Food safety training associated with improved knowledge and behaviours among foodservice establishments' workers. Int. J. Food Sci., 8 pp., Article ID 328761. DOI: 10.1155/ 2015/328761.

2. Adeyanju, G. T., Ishola, O., 2014: Salmonella and Escherichia coli contamination of poultry meat from a processing plant and retail markets in Ibadan, Oyo State, Nigeria. Springer Plus, 139, 3, 1-9. DOI: 10.1186/2193-1801-3-139. 
3. Adwan, G. M., Alqarem, B. R., Adwan, K. M., 2015: Prevalence of foodborne pathogens in meat samples in Palestine. Int. Food Res. J., 22, 5, 1806-1812.

4. Ajayi, O. A., Salaudeen, T., 2014: Consumer food safety awareness and knowledge in Nigeria. Int. J. Food Safety, 16, $17-24$.

5. Akinmutimi, A. H., 2004: Evaluation of Sword Bean (Canavalia gladiate) as an Alternative Feed Resources for Broiler Chickens. PhD thesis, Michael Okpara University of Agriculture, Umudike, 4-17 pp.

6. Akinyemi, K. O., Oshundare, Y. O., Oyeyinka, O. G., Coker, A. O., 2012: A retrospective study of community-acquired Salmonella infections in patients attending public hospitals in Lagos, Nigeria. J. Infect. Dev. Ctries., 14, 6 (5), 387-395. DOI: $10.3855 /$ jidc. 2120 .

7. Annan-Prah, A., Amewowor, D. H. A. K., Osei-Kofi, J., Amoono, S. E., Saka, S. Y. E., Ndadi, H. A., 2011: Street foods: handling, hygiene and client expectations in a World Heritage Site Town, Cape Coast, Ghana. Afr. J. Microbiol. Res., 5, 13, 1629-1634. DOI: 10.5897/AJMR11.199.

8. Apata, E. S., Kukul, I. A., Apata, O. C., Adeyemi, K. O., 2013: Evaluation of suya-an intermediate moisture meat product in Ogun State, Nigeria. J. Food Res., 2, 1, 87-93. DOI: 10.5539/jfr.v2n1p87.

9. Atanda, S. A., Pessu, P. O., Agoda, S., Isong, I. U., Ikotun, I., 2011: The concepts and problems of post-harvest food losses in perishable crops. Afr. J. Food Sci., 5, 11, 603-613. http://www.academicjournals.org/AJFS.

10. Baryrow, G. I., Feltham, R. K. A., 1993: Cowan and Steel's Manual for the Identification of Medical Bacteria, 3rd edn., Cambridge University Press, Cambridge, 140-143.

11. Bernard, P., Jarlier, V., Santerre-Henriksen, A., 2008: Antibiotic susceptibility of Staphylococcus aureus strains responsible for community-acquired skin infections. Ann. Dermatol. Venereol., 135, 1, 13-19. DOI: 10.1016/j.annder.2007.06.004.

12. Brooks, G. F., Carroll, K. C., Butel, J. S., Morse, S. A., 2007: Jawetz, Melnick, \& Adelberg's Medical Microbiology, 24th edn., McGraw-Hill Medical, USA, 831 pp. http://www.mcgrawhill.co.uk/html/0071476660.html.

13. Centre for Disease Control and Prevention., 2008: Preliminary foodnet data on the incidence of infection with pathogens transmitted commonly through food-10 States, 2007. MMWR Morb. Mortal. Wkly. Rep., 57, 14, 366-370.

14. Chhajer, R., Ali, N., 2014: Genetically modified organisms and visceral leishmaniasis. Front. Immunol., 5, 213, 1-10. DOI: 10.3389/fimmu.2014.00213.
15. Chuku, A., Etim, L. B., Obande, G. A., Asikong, B. E., Sani, B. E., 2016: Bacteriological quality of fresh raw beef and chevron retailed in Lafia Metropolis, Nigeria. J. Microbiol. Res., 6, 2, 29-34. DOI: 10.5923/j.microbiology.20160 602.01 .

16. Clinical and Laboratory Standards Institute (CLSI), 2019: Performance Standards for Antimicrobial Susceptibility Testing. 29th edn., CLSI supplement M100. Wayne, PA: Clinical and Laboratory Standards Institute.

17. Conter, M., Paludi, D., Zanardi, E., Ghidini, S., Vergara, A., 2009: Characterization of antimicrobial resistance of foodborne Listeria monocytogenes. Int. J. Food Microbiol., 128, 497-500. DOI: 10.1016/j.ijfoodmicro.2008.10.018.

18. European Food Safety Authority (EFSA)., 2009: The Community summary report on foodborne outbreaks in the European Union in 2007. EFSA J., 271, 1-128. DOI: 10.2903/j. efsa.2009.271r.

19. Elkhishin, M. T., Gooneratne, R., Hussain, M. A., 2017: Microbial safety of foods in the supply chain and food security. Adv. Food Technol. Nutr. Sci. Open J., 3, 1, 22-32. DOI: 10. 17140/ AFTNSOJ-3-141.

20. Fasanmi, O. G., Sansi, J. A. A., 2008: Essentials of Meat and Milk Inspection and Hygiene. 1st edn., Tunmid Printronic, Ibadan, $104 \mathrm{pp}$.

21. Food and Agriculture Organisation (FAO), 2008: Food and Agricultural Organisation. Country Profile: Food Security Indicator, Nigeria. http://www.fao.org/countryprofiles/index/ en/?iso3=NGA.

22. Food and Drug Administration (FDA), 2007: Managing Food Safety: A Regulator's Manual for Applying HACCP Principles to Risk-based Retail and Food Service Inspections and Evaluating Voluntary Food Safety Management Systems. https://www.fda. gov/Food/GuidanceRegulation/HACCP/ucm2006812.

23. Food and Drug Administration, 2013: Bad Bug Book: Foodborne Pathogenic Microorganisms and Natural Toxins Handbook, Staphylococcus aureus. http://www.fda.gov/Food/FoodborneIllnessContaminants/CausesOfIllnessBadBugBook/ ucm070015.htm.

24. Fouladkhah, A. C., Thompson, B., Camp, J. S., 2019: Safety of food and water supplies in the landscape of changing climate. Microorganisms, 7, 469, 1-5. DOI: 10.3390/microorganisms7100469.

25. Gomba, A., Chidamba, L., Korsten, L., 2016: Antimicrobial resistance profiles of Salmonella spp. from agricultural environments in fruit production systems. Foodborne Pathog. Dis., 13, 9, 495-501. DOI: 10.1089/fpd.2016.2120. 
26. Gorton, A., Stasiewicz, M. J., 2017: Twenty-two years of US meat and poultry product recalls: implications for food safety and food waste. J. Food Prot., 80, 4, 674-684. DOI: 10. 4315/0362-028X.JFP-16-388.

27. Havelaar, A. H., Kirk, M. D., Torgerson, P. R., Gibb, H. J., Hald, T., Lake, R. J., et al., 2015: World Health Organization global estimates and regional comparisons of the burden of foodborne disease in 2010. PLoS Med., 12, 12, e1001923. DOI: 10.1371/journal.pmed.1001923.

28. Hoffmann, S., Batz, M. B., Morris, J., Glenn, J., 2012: Annual cost of illness and quality-adjusted life year losses in the United States due to 14 foodborne pathogens. J. Food Prot., 75, 7, 1292-1302. DOI: 10.4315/0362-028X.JFP-11-417.

29. Hudson, J. A., Olsen, L., Cook, R., 2011: Minimum Growth Temperatures of Foodborne Pathogens and Recommended Chiller Temperatures. MPI Technical Paper No. 2016/04. DOI: 10. 13140/RG.2.1.3037.0167.

30. International Livestock Research Institute (ILRI), 2011: Assessment of risks to human health associated with meat from different value chains in Nigeria: using the example of the beef value chain. Nigeria Integrated Animal and Human Health Management Project Draft Report. Nairobi, Kenya: ILRI, 112 pp. https://hdl.handle.net/10568/10251.

31. Ishola, O. O., Mosugu, J. I., Adesokan, H. K., 2016: Prevalence and antibiotic susceptibility profiles of Listeria monocytogenes contamination of chicken flocks and meat in Oyo State, south-western Nigeria: Public health implications. J. Prev. Med. Hyg., 57, 3, E157-E163.

32. Joint WHO. FAO. UNU Expert Consultation., 2007: Protein and amino acid requirements in human nutrition. World Health Organ. Tech. Rep. Ser., 935, 1-265.

33. Kumarasamya, K. K., Tolemanb, M. A., Walshb, T. R., Bagariac, J., Buttd, F., Balakrishnanc, R., et al., 2010: Emergence of a new antibiotic resistance mechanism in India, Pakistan, and the UK: a molecular, biological, and epidemiological study. Lancet Infect Dis., 10, 9, 597-602. DOI: 10.1016/ S1473-3099(10)70143-2.

34. Kim, H. J., Kim, D., Song, S. O., Goh, Y. G., Jang, A., 2016: Microbial status and guideline for raw chicken distributed in Korea. Korean J. Poult. Sci., 43, 235-242. DOI: 10.5536/ KJPS.2016.43.4.235.
35. Kotzekidou, P., 2013: Microbiological examination of readyto-eat foods and ready-to-bake frozen pastries from university canteens. Food Microbiol., 34, 2, 337-343. DOI: 10.1016/j. fm.2013.01.005.

36. Laufer, A. S., Grass, J., Holt, K., Whichard, J. M., Griffin, P. M., Gould, L. H., 2015: Outbreaks of Salmonella infections attributed to beef-United States, 1973-2011. Epidemiol. Infect., 143, 2003-2013. DOI: 10.1017/S0950268814003112.

37. Nigeria Centre for Disease Control., 2018: Lassa Fever Outbreak in Nigeria-Situation Report 06. https://ncdc.gov.ng/ themes/common/files/sitreps/384bdfdc4dcc80de8ad7dc8ea0 a58abe.pdf.

38. Obimdike, O. C., 2016: Assessment of Microbial Load of Meat Sold at Informal and Formal Markets in Ibadan and Meat Sellers' Hygiene: the Public Health Implications. DVM Dissertation, University of Ibadan, Nigeria, $97 \mathrm{pp}$.

39. Okeke, I. N., Aboderin, A. O., Onayade, A. A., 2014: Cholera Control and AMR in Nigeria. Commonwealth Health Partnerships, 67-69. http://www.commonwealthhealth.org/ wp-content/uploads/2014/05/3-Cholera-control-okeke.pdf.

40. Scates, P., Moran, L., Madden, R. H., 2003: Effects of incubation temperature on isolation of Campylobacter jejuni genotypes from food enriched in Preston broth. J. Environ. Microbiol., 69, 4658-4661. DOI: 10.1128/AEM.69.8.46584661.2003 .

41. Scharff, R. L., 2012: Economic burden from health losses due to foodborne illness in the United States. J. Food Prot., 75, 123-131. DOI: 10.4315/0362-028X.JFP-11-058.

42. Singh, V. P., 2018: Recent approaches in food bio-preservation-a review. Open Vet. J., 8, 1, 104-111. DOI: 10.4314/ ovj.v8i1.16.

43. Sofos, J. N., 2008: Challenges to meat safety in the 21 st century. Meat Sci., 78, 3-13. DOI: 10.1016/j.meatsci.2007.07.027.

44. Tambekar, D. H., Jaiswal, V. J., Dhanorkar, D. V., Gulhane, P. B., Dudhane, M. N., 2008: Identification of microbiological hazards and safety of ready-to-eat food vended in streets of Amravati City, India. J. Appl. Biosci., 7, 195- 01.

45. World Health Organization (WHO), 2018: ListeriosisSouth Africa. Disease OutbreakNews. http://www.who.int/csr/ don/28-march-2018-listeriosis-south-africa/en/. Accessed 02 July 2018.

Received April 26, 2019

Accepted February 28, 2020 